\title{
What Youths with Autism Spectrum Disorder and Their Parents Want from Social Competence Programs
}

\author{
Jeffrey W. H. MacCormack \\ University of Lethbridge
}

\begin{abstract}
Program designers develop a wide range of intervention programs to address the social challenges faced by children and youth with autism spectrum disorder (ASD) but it is not clear how those programs are perceived by families of youth with ASD and the extent to which those programs are accessed. To explore the perceptions of families of youth with ASD, 12 youths with ASD and 15 of their parents participated in 4560 minute interviews about social intervention programs and completed the Social Responsiveness Scale, Second Edition. According to the families, the social programs created to help youth with ASD to socialize have not addressed their needs. The adolescents sought programs that provided activities that matched their interests and that were appropriate for their developmental stage. The parents reported that they were frustrated by barriers to service and weaknesses of design, which were obstacles to accessing programs that supported their children's development.
\end{abstract}

Difficulty socializing with others is one of the fundamental diagnostic characteristics of autism spectrum disorder (ASD; American Psychiatric Association [APA], 2013). The consequences of reduced social competence can be profound, regardless of the cognitive and language ability of the youth with ASD (White, Keonig, \& Scahill, 2007). For example, the limited social competence of many youth with ASD can make it difficult for them to integrate into their social networks (Locke, Shih, Kretzmann, \& Kasari, 2015), succeed academically in school (Bauminger-Zviely, 2013), and find employment opportunities later in life (Taylor \& Seltzer, 2011). The social challenges faced by youth with ASD do not diminish with age; in fact, with the onset of 
adolescence, youth experience new and complex social and emotional challenges. Compared to younger children, adolescents with ASD are at greater danger of social exclusion and loneliness (Bauminger, Shulman, \& Agam, 2003; Locke, Ishijima, Kasari, \& London, 2010) because of the social expectations characteristic of high school experiences (Laursen \& Hartl, 2013).

To address the challenges faced by adolescents with ASD, program designers have developed a wide variety of intervention programs that help youth develop and practise skills related to social competence (Reichow \& Volkmar, 2010) in clinical (e.g., Laugeson, Frankel, Gantman, Dillon, \& Mogil, 2012; LeGoff, 2004) and communitybased settings (e.g., Laugeson, Ellingsen, Sanderson, Tucci, \& Bates, 2014). These intervention programs are designed to address the wide variety of difficulties that relate to social competence, such as turn-taking (LeGoff, 2004), taking perspectives (Begeer et al., 2011), recognizing emotions (Tracy, Robins, Schriber, \& Solomon, 2011), and interpreting non-literal language (Norbury, 2005). Even though parents of youth with ASD typically enrol their children in a variety of programs (Goin-Kochel, Macintosh, \& Myers, 2008), with young children with ASD tending to participate in several programs at once (average of 6.44 programs over six months; Kohler, 1999), parents of youth with ASD report feeling dissatisfied with the programs in which they enrol their children (Bitterman, Daley, Misra, Carlson, \& Markowitz, 2008; Crane, Chester, Goddard, Henry, \& Hill, 2015).

While parents and program designers might seem like natural allies, the relationships between them are not always positive. Program designers and parents do not always agree on best way to help youth develop social competence (Noyes-Grosser et al., 2013; Ozonoff, Goodlin-Jones, \& Solomon, 2005). Parents tend to adopt childcentric positions and focus on individual needs and characteristics of the child (Stoner, Angell, House, \& Bock, 2007), whereas program designers tend to focus on deficitcentric positions and look for the program components that help the most participants (Stoner et al., 2005). As a result, program designers may discount the views of parents as peripheral to the developmental goals of the youth and as obstacles to implementation (Stoner et al., 2005), especially when parents' perspectives differ from those held by the program designers (Keenan, Dillenburger, Doherty, Byrne, \& Gallagher, 2010). Even when program designers acknowledge the value of the perspectives of parents to the development of intervention programs (Dunst, Trivette, \& Hamby, 2007; Hartley \& Schultz, 2015), parents often feel excluded from program design and implementation (Tucker \& Schwartz, 2013).

Parental engagement is crucial for the development of young people (Stoner et al., 2007). When families believe in the strategy, they are more likely to initiate and then sustain involvement. Furthermore, parents and youth reinforce and emphasize the social skills that they perceive as the most important (Rankin, Weber, Kang, \& Lerner, 2015). When they feel excluded from the process of intervention development, parents report that they feel extra pressure to search for effective programs, a process they find exhausting and stressful (Brookman-Frazee, Baker-Ericzen, Stadnick, \& Taylor, 2012; Hodgetts, Nicholas, Zwaigenbaum, \& McConnell, 2013; Siklos \& Kerns, 2006). 
The purpose of this study was to establish perceptions of the programs and interventions in which the youths had participated by interviewing parents and youths with ASD (ages 9-17). Examining parents' perceptions of programming may provide a deeper understanding of the challenges they face (Russell \& McCloskey, 2015). Although a few recent studies have looked at the perceptions of parents (McMahon, Lerner, \& Britton, 2013; Stahmer et al., 2016) little is known about how parents perceive programs and make program choices (Hume, Bellini, \& Pratt, 2005). More research is needed to examine the types of services and programs families access (Siklos \& Kerns, 2006) and how families can be integrated into program decisions (Rogers et al., 2014; Wetherby et al., 2014). This study was designed to explore: (a) what goals youths with ASD and their parents seek to accomplish through participation in programs designed to improve social competence, (b) which activities and practices are perceived to promote social competence by youths with ASD and their parents, and (c) which factors affect the decisions of parents of youths with ASD regarding social competence programs. The current study also included questions used to develop a profile of the youths with ASD because parental perspectives should be considered in conjunction with severity ratings of the youths (Frey, Elliott, \& Kaiser, 2014), in that the severity of the child's autism is the strongest predictor of parental stress (Kissel \& Nelson, 2014; Lyons, Leon, Roecher Phelps, \& Dunleavy, 2010). Extended emotional distress of the parents can cause the families to drop out of programming and services (Burrell \& Borrego, 2012).

\section{Method}

The current study examines the perspectives of youth with ASD and their parents on social competence programs. Interviews were chosen for this study because interviews are considered to be powerful tools for understanding the lived experiences of others (Fontana \& Frey, 2000). The method of interviews values the contribution of participants as experts on their own perspectives (Mack, Woodsong, MacQueen, Guest, \& Namey, 2005). Informed consent was obtained from all parents and youths in accordance with the clearance of a university ethics review board. As recommended by the ethics review board, all of the interviews with the youth participants, a vulnerable population, were conducted on speaker phone in the presence of their parents or guardians. Additionally, the interview questions were written in a reading level appropriate for the verbal ability of the participants (see Appendix A). Pseudonyms are used throughout the article when referring to specific participants.

\section{Participants}

Twelve semi-structured interviews were conducted with 12 youths with ASD (ages 9-17) and with 15 parents; for three of the interviews, two parents (mother and father) were present. See Appendix B for brief descriptions of the programs in which the youths had participated. All but one of the youth participants were male. Janey, the only female participant, who was also the youngest, may seem an outlier because of her sex and age, but her perspectives contributed meaningfully to the study. Janey's answers were included in the analyses despite her unique demographics because age and ability 
differences are common among the youths who participate in social programming. The parents in the current study were exclusively mothers when only one parent participated. Two sets of parents had more than one child with a diagnosis of ASD but answered the questions in relation to only the child who participated in this study. Parents were recruited through flyers on social media, listserv emails from ASD associations (e.g., Autism Ontario), and social networks of the participants. Participants were recruited from a range of urban and rural areas. Of the 12 families in the study, four families lived in rural areas (townships with populations of less than 5,000), five families lived in small cities (populations between 100,000 and 150,000), and three families lived in cities (populations larger than 150,000). Gift cards equivalent to $\$ 10$ were given to each youth and each parent.

\section{Procedures}

The interviews lasted 45-60 minutes; I conducted them through video conference or telephone call and recorded them using a digital recorder. Each interview included questions for the youths and questions for the parent (see Appendix A), but parents were present for the entire interview, even when the questions were directed at the youths. The interview format was flexible to allow for combined interviews (youth and adults together throughout the interview) or separate interviews (youths left and were not present during questions directed at adults), depending on the preference of the adults and youths. While most of the families decided to have separate interviews, three families chose to have combined interviews (Janey participated in her parents' portion of the interview; Earl participated in his mother's interview; Ben initially left his mother's interview but came back later to contribute).

The interview questions for the youths focused on their interests and social experiences (adapted from Baron-Cohen \& Wheelwright, 1999). The interview questions for the parents covered three main topics: (a) the youths' previous program experiences (adapted from Learner Profile questionnaire; Alberta Education, 2006); (b) the youths' interests and leisure activities (adapted from the Yale Special Interests Survey; Klin, Danovitch, Merz, \& Volkmar, 2007); and (c) the youths' social challenges and goals (adapted from the Intervention Rating Scale; Martens, Witt, Elliot, $\&$ Darveaux, 1985). The questions were adapted from the original questionnaire formats and phrased in a form appropriate to a semi-structured interview. Parents also answered questions to complete the Social Responsiveness Scale, Second Edition (SRS2; Constantino \& Gruber, 2012) to assess the severity of behaviours characterizing their children's ASD. The SRS-2 is a brief (15-20 minutes) screen for youth with ASD, ages 4-18, designed to assess the severity of social deficits associated with ASD. The SRS-2 includes 65 items and can be completed by multiple raters who have at least a month of experience with the youth. It should be noted that seven of the participating youths have at least one subcategory score below the threshold of the Mild range of SRS-2 scores, and four of the youths have a total score below the threshold for Mild. These results should not be mistaken as evidence that the youths did not qualify as participants with ASD. The participants' diagnoses were determined by medical doctors and psychiatrists. The SRS-2 does not singularly determine the status of a diagnosis (Bruni, 2014), so scores below Mild do not suggest the youths did not have ASD. Instead, the 
SRS-2 provides some insight into the nature of the social challenges faced by the youths in the current study. See Table 1 for the pseudonyms, ages, and SRS-2 T-scores of each youth participant.

\section{Analysis}

The interviews were transcribed and analyzed with a constant comparative method and by using Atlas.ti (Version 7) software. The analyses of the interview transcripts used a three-cycle method. At every step of my data analysis, I used an iterative process to explore the perceptions of parents and youth so that the findings are generated from the responses of the participants. During the first cycle of analysis, short descriptive phrases were applied to the transcripts through line-by-line coding of the content. During the second cycle, the codes were aggregated into broad categories as related to the research questions. During the third cycle, broad thematic codes were derived from the categories. With every cycle, a qualitative approach to analysis was used that included checking back to the original documents in relation to the demographic data and the results of the SRS2 , which provided relevant contextual information for the participants. See Table 2 for an example of the process that moved the original transcript through line-by-line coding, categorization, and the creation of thematic codes.

The responses of parents and youths were analyzed in consideration of the severity of the characteristics of ASD of the youths, as determined by the results of the SRS-2 and by the social profiles as described by the parents. Half of the youths with ASD who participated in the study had characteristics that were categorized by parents and the SRS-2 as severe. When the responses of parents of youths with severe characteristics differed meaningfully from the responses of parents of youths with less-than-severe characteristics, the two perspectives are described separately.

\section{Results}

The results are organized by the three research questions and the themes that emerged from the analysis. The first research question, "What goals do youths with ASD and their parents seek to accomplish through participation in programs designed to improve social competence?" is examined through three themes: (a) social skills, (b) emotional well-being, and (c) developmentally appropriate behaviours and skills. The second research question, "Which activities and practices are perceived to promote social competence by youths with ASD and their parents?" is explored through three themes: (a) individualized, (b) interest-based, and (c) interactive. The third research question,

"Which factors affect the decisions of parents of youths with ASD regarding social competence programs?" is considered by exploring access to and features of both (a) clinical programs and (b) community-based programs. The themes that emerged through the cycles of analysis represent areas of general agreement of the participants, as indicated in Table 3. 
Table 1

Pseudonyms, Ages, and SRS-2 T-Scores of Youth Participants

\begin{tabular}{llccccccc}
\hline Parents & Youths & Age & AWR & COG & COM & MOT & RRB & TOT \\
\hline Jeannie, Adrian & David & 14 & 64 & 59 & 52 & 44 & 73 & 58 \\
Lynette, Erik & Janey & 9 & 51 & 58 & 59 & 42 & 76 & 58 \\
Darla, Tony & Charlie*** & 13 & 67 & 68 & 85 & 69 & 88 & 79 \\
Lori & Gene & 17 & 89 & 65 & 82 & 82 & 87 & 84 \\
Irene & Fred & 17 & 89 & 78 & 78 & 50 & 89 & 90 \\
Grace & Ben & 17 & 60 & 54 & 52 & 60 & 50 & 54 \\
Carolyn & Earl* & 17 & 38 & 50 & 63 & 75 & 78 & 64 \\
Erin & Maurice** & 16 & 76 & 77 & 83 & 85 & 85 & 87 \\
Kate & Cesar* & 12 & 76 & 85 & 81 & 77 & 77 & 83 \\
Cheryl & Terrell & 17 & 51 & 39 & 46 & 50 & 51 & 47 \\
Gretchen & Gustavo* & 13 & 82 & 66 & 72 & 85 & 85 & 81 \\
Maxine & Dwight & 13 & 67 & 63 & 71 & 52 & 62 & 66 \\
\hline
\end{tabular}

AWR=social awareness; $C O G=$ social cognition; $C O M=$ social communication; $M O T=$ social motivation;

$\mathrm{RRB}=$ restricted, repetitive behaviour; TOT=total SRS-2 score; Mild=60-65, Moderate $=66-75$, Severe $=>76$

Comorbid diagnoses according to parents: *anxiety disorder ${ }^{* *}$ high IQ, gifted ${ }^{* * *}$ global delay, partially verbal 
Table 2

Example of Three Cycles of Analysis on Section of Interview Transcript

\begin{tabular}{|c|c|c|c|}
\hline Transcription & Line-by-line coding & Category & Theme \\
\hline $\begin{array}{l}\text { They had a lot of brain fitness things. It was good for } \\
\text { his working memory and attention span. They weren't } \\
\text { good at core curriculum. }\end{array}$ & $\begin{array}{l}\text { brain fitness } \\
\text { cognition }\end{array}$ & $\begin{array}{l}\text { direct } \\
\text { instruction }\end{array}$ & social goals \\
\hline $\begin{array}{l}\text { They didn't have anything for social stuff. They had a } \\
\text { wide range of social needs. They had varying abilities. }\end{array}$ & $\begin{array}{l}\text { poor social } \\
\text { programming }\end{array}$ & $\begin{array}{l}\text { gaps in } \\
\text { instruction }\end{array}$ & $\begin{array}{l}\text { weaknesses of } \\
\text { programming }\end{array}$ \\
\hline $\begin{array}{l}\text { They advertised as "come here and avoid bullying" and } \\
\text { then that was the only place he was bullied. I paid } \\
\$ 20,000 \text { a year for it. It was good at first. }\end{array}$ & $\begin{array}{l}\text { bullying } \\
\text { expensive }\end{array}$ & costly & $\begin{array}{l}\text { barriers to } \\
\text { program } \\
\text { (cost) }\end{array}$ \\
\hline $\begin{array}{l}\text { I've found that little kids that age can be [difficult]. He } \\
\text { probably would have come across that on his own. } \\
\text { And some kids started to mature past him. We're still } \\
\text { dealing with the aftermath of that. } \\
\text { There was some kid who beat him at sports and rubs } \\
\text { his nose in it. } \\
\text { We're still not over it. He still won't play sports because } \\
\text { he doesn't feel good about it. }\end{array}$ & $\begin{array}{l}\text { bullying } \\
\text { emotional } \\
\text { impact }\end{array}$ & $\begin{array}{l}\text { working with } \\
\text { peers } \\
\text { (negative) }\end{array}$ & $\begin{array}{l}\text { emotional } \\
\text { goals }\end{array}$ \\
\hline
\end{tabular}




\section{Table 3}

Frequency of Direct Quotations Used by Participant by Themes

\begin{tabular}{|c|c|c|c|c|c|c|c|c|c|c|}
\hline \multirow[b]{2}{*}{ Adults } & \multirow[b]{2}{*}{ Youths } & \multirow[b]{2}{*}{ Interview } & \multicolumn{3}{|c|}{$\begin{array}{c}\text { Theme 1: } \\
\text { Program Goals }\end{array}$} & \multicolumn{3}{|c|}{$\begin{array}{c}\text { Theme 2: } \\
\text { Activities and Practices that } \\
\text { Promote Competence }\end{array}$} & \multicolumn{2}{|c|}{$\begin{array}{l}\text { Theme 3: } \\
\text { Factors Affecting } \\
\text { Decisions }\end{array}$} \\
\hline & & & Social Skills & $\begin{array}{l}\text { Emotional } \\
\text { Well-being }\end{array}$ & $\begin{array}{l}\text { Develop- } \\
\text { mental } \\
\text { Factors }\end{array}$ & $\begin{array}{l}\text { Individ- } \\
\text { ualized }\end{array}$ & $\begin{array}{l}\text { Interest } \\
\text { Based }\end{array}$ & Interactive & $\begin{array}{l}\text { Features, } \\
\text { Access: } \\
\text { Clinical }\end{array}$ & $\begin{array}{l}\text { Features, } \\
\text { Access: } \\
\text { Community }\end{array}$ \\
\hline Jeannie, Adrian & David & Separate & Q & Q & $\mathrm{T}$ & Q & $Q$ & - & - & $\mathrm{T}$ \\
\hline Lynette, Erik & Janey & Combined & $Q$ & $Q$ & $\mathrm{~T}$ & Q & $\mathrm{T}$ & Q & $\mathrm{T}$ & $Q$ \\
\hline Darla, Tony & Charlie & Separate & Q Q & $\mathrm{T}$ & - & $Q$ & $Q$ & $Q$ & Q Q & $Q$ \\
\hline Lori & Gene & Separate & Q Q & - & Q & - & $Q$ & Q & Q & $\mathrm{T}$ \\
\hline Irene & Fred & Separate & $\mathrm{T}$ & $Q$ & $Q$ & $Q$ & $\mathrm{~T}$ & - & - & $\mathrm{T}$ \\
\hline Grace & Ben & Combined & $\mathrm{T}$ & Q q & - & $Q$ & $q$ & $Q$ & Q Q & Q Q \\
\hline Carolyn & Earl & Combined & Q q & Q Q & Q & Q Q & Q q & Q & Q Q & Q Q \\
\hline Erin & Maurice & Separate & $Q q Q$ & $Q$ & - & $\mathrm{T}$ & $Q$ & $\mathrm{~T}$ & - & $Q$ \\
\hline Kate & Cesar & Separate & $\mathrm{T}$ & $Q$ & $Q Q$ & Q Q & $Q$ & $Q$ & $Q$ & $\mathrm{~T}$ \\
\hline Cheryl & Terrell & Separate & Q q & - & $\mathrm{T}$ & Q Q & - & - & Q & - \\
\hline Gretchen & Gustavo & Separate & Q & Q & - & - & Q & Q & Q & Q \\
\hline Maxine & Dwight & Separate & $Q$ & Q Q Q & $q Q$ & $Q$ & $Q$ & - & - & $Q$ \\
\hline
\end{tabular}

$Q=$ direct quotation used (adult); $q=$ direct quotation used (youth); $T$ = topic was discussed, but direct quotation was not used 


\section{Program Goals}

Parents of youths with ASD identified three main areas of focus as most important to the development of social competence. First, parents reported that they wanted programs to directly address their youths' social skills. Second, parents wanted the programs to support their youths' emotional well-being. Third, parents wanted programs to be designed to reflect the changing requirements of their youths' development and context.

Social skills. Above everything else, parents of youths with ASD tried to choose programs with outcome goals that addressed the particular social needs of their child. Parents with children with severe characteristics tended to identify the development of fundamental social skills (e.g., "to be able to ask us questions," Tony); "to have an ability to take perspectives," Gretchen) or the reduction of non-preferred behaviour (e.g., "going out in public without getting too aggressive," Lori) as most important. Parents of children with less-than-severe characteristics also identified particular goals (e.g., "don't sound too silly," Maxine), but in general the social goals they emphasized tended to be broad (e.g., "to have more regular friendships," Carolyn) and vague (e.g., "to have a normal, healthy social life," Cheryl), and to include complex social skills (e.g., "to get some improvement in a group setting," Lynette). Adrian described the goals for his son's social development as, "speaking kindly to his sisters, thinking of others, respecting his elders."

Although the needs of the youths varied, their parents had clear ideas of what the youths needed. Further, the social skills that parents identified as valuable for their children's development aligned with the results of the SRS-2. For example, Tony reported that his priority for Charlie, whose social communication was listed as severely restricted ( $T$-score, 85), was the development of clear speech: "[The other kids] don't understand him so if he had the actual skill of, not vocabulary, but speech language skill, that would definitely help." In the case of Gene, for whom social awareness was identified as severely restricted ( $T$-score, 89 ), his mother said that he would do better socially if he were more aware of how others perceived him: "He is a really big guy, so he can be intimidating. He comes off as a little aggressive" (Lori). For Maurice, whose social motivation was rated as severely restricted ( $T$-score, 85 ), his mother reported that "the piece that is missing is the 'why' he would want to [make friends]. He doesn't see the benefit of putting in the time ... he will say, 'I would rather play my video games"' (Erin).

In a few cases, the youths were also able to identify which program goals would best help them to socialize. When asked what would help him co-operate with others, Earl, whose greatest challenge was identified as restricted and repetitive behaviours ( $T$-score, 78), identified social skills that related to restricted interests as most important: "Breaking my autistic habits. Not getting stuck on my personal interests and getting stuck on talking about them all the time." Maurice, a youth whose primary social difficulty related to social motivation, reported: "I find small chitchat more stressful than high concept politics and music. I find small talk stressful because I don't know where the conversation is going." Maurice's view of his own social challenges (e.g., "I tend to not socialize with other people; I tend to find social situations awkward and mentally straining") agreed with his mother's view of his social challenges (e.g., "He found it hard to interact with the other kids; he found it socially awkward," Erin) and his SRS-2 results (e.g., social cognition and 
communication severely restricted). While Earl and Maurice were able to identify their social needs, most of the youth participants were not. Answers like the one from Terrell, a youth, "I get along fairly well. I can't think of any time we've had arguments," were typical of the youths, who often overestimated their social capacities.

Emotional well-being. While parents sought programs that they believed would help their children improve their social skills, they were also concerned with their children's emotional well-being, and maintaining it was very important to them (e.g., "He just needs more self-esteem. More confidence" Kate, parent). The importance of keeping youths happy and stable was demonstrated by an outburst by Ben during an interview with his mother, Grace. During the interview, Grace was answering questions about how difficult cooking class was for Ben ("He took a cooking class with the Autism Society. He didn't like it."); and Ben, misunderstanding her tone, shouted from the other room: "No, you're lying. I don't have any friends. I didn't like any of those groups. I didn't like any of them!" Like Grace and Ben, other parents and youths reported that the occasions when the youths were miserable were very challenging for the youths (e.g., "There were always tantrums," Gretchen, parent) as well as for the parents ("It was heart-breaking," Irene, parent). Even when playing in the neighbourhood, the youth participants were susceptible to social exclusion and emotional distress. Erik said that misunderstanding during unstructured play caused emotional challenges for his daughter, Janey:

Especially in a big group here in the neighbourhood, she feels like they are picking on her, maybe because she is the youngest. It is easy to get, like when they are playing tag. She doesn't understand that sort of thing. She gets frustrated and she comes in to complain to us. That's our biggest challenge, to have her play in groups.

Parents were additionally concerned with the emotional well-being of their children because unhappy children often caused program refusal: "If he is uptight and worried, he is not going to learn" (Maxine, parent). Parents identified two threats to the youths' emotional well-being: direct pressures from other program participants and indirect pressures from the structure of programs.

According to the parents, youths with ASD were sensitive to unkind words of other youth participants. As one mother explained, teasing from another boy in the program had long-lasting effects:

I've found that little kids that age can be [difficult]. He probably would have come across that on his own. And some kids started to mature past him. We're still dealing with the aftermath of that. There was some kid who beat him at sports and rubbed his nose in it. We're still not over it. He still won't play sports because he doesn't feel good about it. (Carolyn)

Besides the direct threat of unkind words, parents reported that the structure and content of the programs also posed threats to the youths' emotional well-being. Parents reported that youths with ASD may not perceive the differences between their own development and the development of typically developing children until the differences were made plain in specialized programs:

In some ways, [programs] have really lifted the curtain so we see the differences between [him] and the other kids easily. We see the societal expectations. It has been 
hard on him because the more he is involved in something, the more he sees that he is different. (Erin)

Even though parents tended to seek out intense programs, they also looked for programs that they perceived as being compassionate: "Back then when I looked into applied behaviour analysis ... it was more like training a dog. And it looked meanspirited and I wouldn't do it to my kid" (Carolyn). Parents of youths with ASD were very concerned with their child's emotional state:

What it comes down to, in these particularly crucial years in his life, his preteen years, he's developing a sense of self-esteem and confidence ... You don't get a second chance at your sense of self-esteem and your sense of confidence. It is going to be harder to build on if it has been depleted. (Maxine)

While most parents considered inclusive settings to be crucial to their children's development, some parents worried that interacting with typically developing peers in school and programs could negatively impact self-esteem of the youth with ASD: "He speaks to the kids, but he doesn't feel a part of it" (Carolyn). As an adolescent with ASD, the frustration Earl felt toward typically developing peers at his school was made clear through his choice of language: "I used to be not that confident in myself [because] ... high school is full of judgmental assholes, you know?" Conversely, programs that only included youths with ASD were perceived as safe places for youths with ASD. Gretchen reported that her son, Gustavo, flourished emotionally when he participated in a live-in hospital program for youth with exceptionalities: "They were a little clique or group. They had the same type of problems and they got along really well ... He thrived in that environment!" Parents reported that participating in programs with other youths with ASD provided a context of acceptance and tolerance: "The best thing about that is that the other kids have the same type of personality. There is no social awkwardness. Nobody thinks he is weird [and so] he'll make a friend" (Maxine). Adrian reported that the welcoming environment created by having numerous youth with exceptionalities helped his son, David, to be successful: "They were really accepting of different types of kids, and a lot of the families had children with different types of needs. It made it easier to fit in."

Developmentally appropriate behaviours and skills. In addition to the program goals that related to social skills and emotional well-being, parents of youths with ASD wanted programs to be designed to reflect the changing needs of the youth's developmental stages. The needs of youths with ASD were influenced by personal factors (e.g,. maturity, language development) and external factors (e.g., acceptance, social exclusion). According to his mother, Lori, Gene's social acceptance among his peers has been hampered by his physical development: "He is a really big guy, so he can be intimidating. He comes off as a little aggressive." Dwight, a youth, reported that his ability to connect with typically developing peers depended on his maturity:

There is one kid in my school. We were best friends in Grade 3 [then] we started not being friends. In Grade 4 to 7, we started having a fight. He stopped being my friend. I used to be immature, but now I'm mature.

Parents reported that the move from elementary school to secondary school brought new social and emotional changes: "He finds that [typically developing] kids in his class - they're 13 - their attitudes are changing. Everyone is too cool for school. They 
don't want to talk. They don't want to show excitement" (Maxine, parent). Social goals change as the youths with ASD move into new stages and interact with different youth: "It's kind of sad in one respect that I have to say to him, the goal is that, as you enter high school, you're going to have to watch what you say" (Kate, parent). Parents recognized that although a program might be well-suited for their child at one stage of development, the program might not be appropriate as the youth developed further. Irene expressed her anxiety about the changing needs of her son, Fred, as he develops into adulthood:

I'm 53. What is going to happen when [unfinished sentence]. He is going to need something to go to when he is in his 20 s. What if he needs to live on his own? We need to set something up for these kids who don't get access to housing programs. They need the help and the guidance.

Parents reported that programs have to consider the developmental stages of the participants because, as they grew into adolescence, the youths with ASD were less willing to interact with others who were developmentally below them. Carolyn reported that programs could fail if the other kids were not at the same level as her son: "Programs fail when he feels the others are beneath him." Parents reported that they sought developmentally appropriate programs and abandoned program decisions if the program design did not reflect their youth's changing needs: (e.g., "If he knows something is going wrong, he will leave the situation," Kate).

In sum, the primary function of social competence programs in the minds of parents is that they help youths to develop social competence. That goal, however, is not the only concern of parents. Parents also look for programs that provide safe places for youths to develop. Additionally, parents look for programs that reflect, and support the youth through, their developmental stages.

\section{Practices and Activities Perceived to Be Effective}

Youths with ASD and their parents identified three program elements as effective practices for programs of social competence. First, parents and youths with ASD reported that effective programs were individualized for the youths. Second, parents and youths with ASD identified the inclusion of interest-based activities as crucial to effective programs. Third, youths with ASD and their parents described effective programs as those that included opportunities for meaningful social interactions.

Individualized support. Parents believed that their children required strategies aligned with specific needs and so, as often as possible, they sought programs that were customized for their child. Carolyn, a parent, reported that programs were most effective when "they customized things for how functional the kid is, rather than all the kids trying to access the same program." According to Tony, a parent, having individualized support for his son's speech difficulties was crucial for success: "If he could speak more clearly, he would do much better. That is the barrier for other people: They don't understand him. A speech language pathologist would definitely help." Adrian reported that individualized training on how to listen would be the best fit for his son, David:

Learning to listen to other people is a big one. He likes to talk and his interests are easy to share, but he has to understand that not everyone is as interested with the 
topic as he is, that is the way with a lot of people and with teenagers, and that is something that he is not attuned to, even in his own family.

Several parents highlighted specific programs, such as applied behaviour analysis, as examples of individualized programs. Individualized programs were considered effective because "they stress one concern or a couple of concerns or something that you would like to change" (Grace).

In addition to focusing on relevant goals, parents reported that another important component of individual attention was the inclusion of developmentally similar youth participants. Appropriate peer involvement is a form of individualized support. For example, Cheryl chose programs for her son that included peers "that [were] truly his peers, and not affected or challenged with ASD more than he [was]." Maxine also emphasized the value of developmentally similar youths. According to Maxine, when her son, Dwight, interacted with developmentally similar youths, "he [was] completely at ease and he [had] conversations." Janey's mother, Lynette, reported that the programs that Janey joined were not specific to her needs: "The programs were very generalized, they were too generalized for someone who is high functioning and ... there were only a few people who were at the same level. Some kids needed a whole schedule to get through the day."

In terms of program structure, parents reported that programs that included one-onone support were better suited for individualized instruction. Parents preferred programs that had low instructor-to-youth ratios because the needs of individual youths could be addressed. Several parents identified karate as a program that was attractive because it provided some "one-on-one [support] in a group" (Kate). Parents such as Cheryl looked for programs that initially began with individual support and moved to group support:

So, they started off with [him] starting off in a one-on-one environment... They watched little videos and go into the community and practise what they had seen, or watched on the video. The way that they started off one-to-one, practising what they were learning, and then moving to 2-to-1 ratio, then moving to a larger group from there ... seemed to be the best program out of all of them.

If the program did not include one-on-one support, parents and youths with ASD said that individual workers, such as respite workers and educational assistants, were an effective way to bring individual support to a program. When partnered with an individual worker, youths with ASD were able to participate in activities that would otherwise be too challenging:

This past summer he went to a day camp for two weeks. Luckily, we got a respite worker to go with them. A one-on-one worker. He was able to go to the camp with the respite worker. (Kate, parent)

To parents and youths with ASD, individualized program support was crucial, and losing it was considered detrimental to the youths' development (e.g., "He has lost [education assistant] support, but he still needs someone to help him scribe," Irene, parent). If individualized support was not available, many families found ways to incorporate independent workers. When Carolyn, a parent, could not find a program to provide guided social interactions, she hired a social worker to take her son into the community: "I wanted to see if they could find social opportunities." 
Interest-based programs. The youths in the current study expressed interest in diverse and heterogeneous topics. When asked to describe their interests, all of the youths identified at least five different activities (e.g., "I play the mandolin ... I'm hoping to get a pan flute ... I like carving. I am into carpentry ... I have an old-fashioned radio. I also like crafts," Ben). According to parents, those topics of interest were vital to the design of effective programs for social competence. The parents reported that youths with ASD often resisted social programs (e.g., "He hated it. He screamed and cried," Carolyn), but could be persuaded to participate if the topic or activity was interesting. For example, Gretchen said that, even though her son "hated" programs and often refused to go, he was motivated to participate in programs based around his interests: "If I was going to teach him social skills, it would have to be around his interests." When looking for programs to help Cesar, Kate said, "I try to find something that interests him. We've gone through a variety of different ones... Now that he can voice his opinion, I ask him." Charlie was more patient during his social-skills swimming class because, as his father, Tony, described, "swimming is his favourite sport." When asked to describe the ideal program for her son, Gene, Lori said, "Anything to do with an animal. He wants to be zoologist."

Another advantage of interest-based programs was that youths bonded with one another when they shared interest in the topic. Socializing with typically developing friends may be difficult if those friends do not share the same interests as youth with ASD: "Neurotypical friends his age don't hold a lot of interest. They aren't interested in things he's interested in," (Maxine). Choosing topics of common interest was an effective way for youths with ASD to initiate and sustain conversations. Grace said that for her son, Ben, an interest in music was a powerful tool for connecting with others: "He'll do a whole conversation with someone if he is interested in what is going on at the time." Parents in the current study reported that when the youth could not find people to share their interests, they felt disconnected from the programming goals:

What he wants to talk about is not to the interests of a general 17-year-old. He doesn't fit into the typical programming. We tried the local autism social events, but he didn't find it very helpful. He found it hard to interact with the other kids. $\mathrm{He}$ found it socially awkward. (Erin, mother)

In addition to the value of sharing common interests, youths with ASD and their parents reported that participation in interest-based programs improved communication skills. Parents believed that when youths with ASD have opportunities to converse with others on shared topics of interest, the youth can learn social etiquette and making initiations. Adrian said of his son, David:

He likes to talk and his interests are easy to share, but he has to understand that not everyone is as interested with the topic as he is. That is the way with a lot of people and with teenagers, and that is something that he is not attuned to, even in his own family.

Earl, a youth with ASD, identified the conversation skills he learned in interestbased programs as important to his overall development: "It was strenuous for me to get stuck on one thing. All I would talk about is my interests. But now I'm more versatile."

Social interactions. According to parents, youths with ASD need to do more than passively participate in the activity of the program. To fully benefit from the programs, youths with ASD need to interact with other youth. Janey's father, Erik, reported that 
while she made some progress with one-on-one interactions, "she just has to get some improvement in a group setting, that's what she needs!" Group-setting social interactions were implemented through programs in a variety of ways. For example, parents reported that social interactions were possible through the application of structured play. When participating in structured play, players were forced to interact with each other by the inclusion of roles, objectives, and rules, which were designed to foster interactions. Being forced to interact with others by the structure of the program was considered to be good practice for youths with ASD. When asked what a perfect program for Charlie would include, Tony, his father, described a structured play activity that required interactions:

I would design a program where other kids needed [his] help. All successful conclusions would require collaboration. "This is your part, and this is your part. And when we get through Steps 1 and 2 alone, we need to work together to do Steps 3 and 4."

Parents also identified having a close friend in the program as a way to include social interactions in program design. Not only did socializing with a close friend improve rates of interaction, but youths who found a friend in the program were motivated to sustain involvement. Gretchen reported that, even though her son, Gustavo, disliked sports and refused to attend sport-based programs, he was willing to participate in rock climbing when "one of the kids from class, who he thought was his best friend, was there."

For many of the youths in the study, sharing knowledge with others was another way to interact. When youths with ASD had opportunities to pass on their knowledge, they were motivated to interact with others. For example, Lori said that even though her son, Gene, had a difficult time socializing with other youths, he was willing to do it as part of his life skills program: "He did a week of life skills. He went to the fire hall and learned to use a fire extinguisher, and then he was teaching others to use a fire extinguisher." Helping others was motivating for many of the youth in the current study: "He will participate if he thinks that he is helping others" (Carolyn). Contrary to the perception of youth with ASD as isolated and self-centric, many of the parents said that their children "like to be supportive" (Grace). Kate reported that her son, Cesar, was highly motivated to teach other youth:

Every day he is dismissed out of his class early, and he helps the teacher get the students ready. He helps the Kindergarten kids. He helps them get their lunch bags ready and get their boots on, things like that. He has helped with the Breakfast Club, which is just before the bell rings. He likes to do a lot to help the younger kids.

In sum, youths with $\mathrm{ASD}$, like most people, tend not to want to participate in programs that are not engaging. Youths and their parents perceived that the programs that provided interesting activities are the most engaging, especially when the program allowed for individual attention and provided opportunities for social interactions.

\section{Factors Affecting Program Decisions}

While parents of youths with ASD had clear goals and could identify which practices and activities they considered most effective, they could not always access the programs they considered to be the best match for their children's needs. Parents reported 
that clinical programs (e.g., intensive behaviour interventions, transcranial magnetic stimulation) were highly sought after but difficult to access. Nearly every parent mentioned at least one clinical program that they wanted to access but, because of barriers to service, could not: "The [PEERS program] full price was too much. That is a problem," (Grace). Families who could not access their preferred programs reported that they felt desperate (e.g., "We join whatever is available, whatever they will allow us to do," Grace) and turned to community-based programs run through local libraries and autism associations (e.g., Movie Night, Teen Cuisine, Respite Weekend). While parents did not generally consider community-based programs to have the evidence base of clinical programs, parents enrolled their children in community-based programs because those programs were more accessible. According to parents, the factors that affected their decisions for programs were the barriers and weaknesses related with clinical and community-based programs.

Clinical programs. Families of youths with ASD identified clinical programs as the best programs for their youths but, for many families, cost and location were barriers to accessing these programs. Of the 12 families in the current study, two parents reported that they were able to pay privately for clinical programs (e.g., "Even though our funding was cut off, we're managing to scrape together money to continue his therapy," Tony). The costs of clinical programs were too high for the other families in the study (e.g., "To pay the full price was too much. That is a problem," Grace, parent). For families who could not afford clinical programs, applying for government funding was the next option. Unfortunately, parents reported that the waitlists for program funding were quite long (e.g., "ABA might help. Now, we're on the waiting list for that," Kate). An additional barrier of government funding was that the funding covered a limited block of program sessions. Carolyn described her frustration with accessing public funding for programs: "The biggest thing about publicly funded anything is that you don't get enough. The 10block sessions they do are useless.... What is the point?" Cheryl thought her son could benefit from more sessions of a government-funded program: "It was a good program, but the difficulty was that it was so limited in time and scope. Again, once you took the course ... you couldn't take it again."

Location was another barrier to clinical programs. Parents reported that, because many clinical programs were associated with hospitals and universities, clinical programs were not available outside of major urban areas. For families who did not live in a city, the travel time was an obstacle to service (e.g., "Anywhere in the city is about 45 minutes to an hour away. We find that transportation is always a concern. It is more difficult to go," Lori). Finding ways to schedule in the extra travel time during the school week was particularly difficult for Carolyn:

The problem was the drive. It started at 5 . So, I had to get him out of school early to get downtown for 5. I had to feed him McDonald's or some crap so it was a 5-hour thing for a 90-minute session. [The program] was useful but when you added [the extra time], it was stressful for both of us.

While clinical programs were considered to be the most effective programs, two parents (i.e., Tony, Gretchen) highlighted transferability as a weakness of clinical programs. Tony and Gretchen reported that the transfer of skills learned in specialized 
contexts, such as clinics or isolated rooms, to natural settings, such as classrooms and playgrounds, was limited: "The goal of intensive behaviour intervention is communication.... Occasionally we will go to the park, but there are limited social interactions. Social interaction that we see from this end is limited" (Tony). Gretchen described her frustration with a university-affiliated social skills program: "He theoretically passed but I don't know if I saw any differences.... He couldn't take the learning and apply it to the situation when he was feeling emotional."

Community-based programs. Parents reported that there were fewer barriers to community-based programs than to clinical programs. To fill the gap left when clinical programs were not accessible, parents like Grace signed her son up for any communitybased programs that were available: "We go to [local] autism events. We do do things like that. We go to their movies. Their boat rides. The swimming pools, and kiddie farms. Tree farms. Any get-together." Parents in the current study reported that communitybased programs were organized through local chapters of autism associations (e.g., Autism Ontario) in many small- and mid-sized cities, and so they were accessible for families living in rural areas and small towns. Compared to clinical programs, the costs of community-based programs were low. In fact, several parents said that organizing associations often supplemented the costs of attending organized events: "It was fun to get out and do different things [that] we couldn't afford normally" (Grace). Charlie's father, Tony, reported that community-based programming supported Charlie's development because Charlie needed opportunities to practise social interactions: "We don't have organic situations for him to socialize. We can't bring him to play with children of my friends. He's limited to, basically us, and people he can interact with at those places." Also, community-based programs were available in more locations than clinical programs.

While community-based programs were much more accessible for families of youths with ASD, parents identified two main weaknesses in the programs: (a) program specificity and (b) staff training. Parents reported that community-based programs were designed to include as many youths as possible and, therefore, could not address specific challenges faced by individuals in the program (e.g., "[The program] was a failure because the kids weren't as far along as he was," Carolyn). The wide range of developmental needs of the youths in community-based programs meant that some youths "found it hard to interact with the other kids and ... [felt] socially awkward" (Erin). Erik reported that Janey did not find community-based programming useful because they were not designed to address her specific needs: "It is a mixed blessing that there is nothing they can do to help her out." The value of many community-based programs was nothing more than a forum for networking (e.g., "A lot of time the parents will meet each other, get to talking and exchange phone numbers," Maxine).

Another weakness of community-based programs identified by the parents was the lack of trained staff. According to Carolyn, her son, Earl, could not complete an overnight camp experience because the staff was unprepared for her son: "They couldn't handle him at the time. They supposedly specialized in it, but they couldn't handle him." Gretchen reported that poorly trained staff was the reason why her son could not continue attending gymnastic classes: 
He was kicked out of two gym clubs, which still bothers me because, I get it that he was a danger to other kids if he was running around, but if [program staff] worked with him and accepted him, it might be something else that he is interested in now.

In sum, parents look for the best programs they can access. When possible, parents chose clinical programs affiliated with universities or hospitals. Factors such as cost and location meant that many parents and families could not access their preferred programs. When clinical programs were not accessible, parents turned to community-based programs to help their children.

\section{Discussion}

The current study sought to explore the perspectives of youths with ASD and their parents on the considerations and factors related to social competence program decisions. According to parents and youths, the specific social needs of the youths need to be considered along with the youths' emotional and developmental needs. When asked to describe effective program design, parents and youths identified individualized, interestbased, and socially interactive activities as the best ways to support the youths' social competence. Accessing programs that included those best practices was a high priority for parents of youths with ASD but their efforts were, at times, frustrated by the barriers to programs and weakness of designs. Not having access to the best programs meant that parents had to make difficult decisions as they navigated a network of programs with varying levels of effectiveness. The following discussion is organized to parallel the topics of the results section: (a) what parents want from programs, (b) practices and activities perceived to be effective, and (c) factors affecting program decisions.

\section{What Parents Want From Programs}

Despite some evidence that suggests that researchers and program designers know best what youths with ASD need from social competence programming, the parents and youths in the current study had a strong sense of the youths' social difficulties. The results of the current study extend the results of previous research (e.g., Bellini, Peters, Benner, \& Hopf, 2007; Cunningham, 2012; Matson, Matson, \& Rivet, 2007) demonstrating that consulting with parents and including measures of the social validity of programs (Gresham \& Lambros, 1998) are important steps in program design and implementation. Social validity is the measure of how valuable parents and other stakeholders consider the program outcomes and methods to be (Bellini et al., 2007; Cunningham, 2012). Parents are more likely to initiate and sustain their child's involvement when they believe the goals and strategies of the program are helpful (Brookman-Frazee, 2004). Additionally, parents of youths with ASD can contribute to the process of program design (Hartley \& Schultz, 2015). Even if they lack formal training, parents of youths with ASD are well positioned to understand the social challenges faced by their children because they see their children in a wide variety of social situations and over the span of the children's lives. As demonstrated by the families in the current study, parents have specific goals in mind for the interventions and, from that vantage point, seek strategies that will match those goals. By including 
measures of social validity, program designers can learn from parents which strategies and outcomes are best for the youths.

Results from the current study suggest that, while many youths with ASD have difficulty understanding the nature of their social challenges, some youths with ASD can describe their own social challenges. Of the 12 youth participants, five youths expressed an understanding of the severity of their social characteristics that aligned with the perspectives of their parents and the results of the SRS-2. Given that youths with ASD usually show little understanding of the differences between their own social capacity and normative socializing (Rankin et al., 2015), the finding that some of the youths could express their social challenges was somewhat surprising. Previous studies have shown that youth with ASD tend to have overly positive views of their social competence, compared to the views of their parents, with this phenomenon more pronounced when the youths' social difficulties are more severe (e.g., Tantam, 2000). Youth with ASD, especially those who are high-functioning, may know their social challenges and be able to contribute that knowledge to the design and implementation of programs for social competence.

While the parents in the current study reported feeling desperate to find programs that helped their youths develop social skills, their children's emotional needs were also important. Parents reported that they avoided inclusive programs, if interacting with typically developing peers might harm the child's self-view. The anxieties expressed by the parents and youths with ASD in the current study around inclusive programs aligned with the findings of similar studies on the attitudes of families toward inclusion. While parents generally hold positive views of inclusion practices (Gallagher et al., 2000), they tend to be concerned about the quality of individualized support and the level of social cohesion in these programs (Hodgetts et al., 2013; Iadarola et al., 2015). When designing programs that include typically developing peers, program designers need to consider the anxiety felt by parents and youth with ASD around the potential for social exclusion by typically developing peers. Program designers may be able to reduce the anxiety of youth and parents by creating opportunities in safe contexts with purposeful and structured interactions (e.g., LeGoff, 2004; MacCormack, Matheson, \& Hutchinson, 2015).

\section{Practices and Activities Perceived to Be Effective}

While parents identified practices and activities from both clinical and community programs as effective, the parents in the current study appeared to value programs based in clinical settings over programs based in community settings, despite the advantages offered by community programs, such as naturalistic setting and low cost. This finding is in line with other studies of parental perceptions of program efficacy, which have found that parents seek out clinical programs, and rate their effectiveness more favourably than community-based programs (Goin-Kochel, Mackintosh, \& Myers, 2009). In the views of the parents in the current study, interventions based on empirical evidence that was collected in a clinical setting are the most likely to help their children. The preference of parents to include their children in programs has two main implications for program design. First, community-based programs should be designed to incorporate the evidencebased features that make clinical programs so attractive to parents. Second, program 
designers should, at every opportunity and in a variety of ways, evaluate and improve the effectiveness of community-based programs.

In finding that youths with ASD were highly motivated to participate in activities based on their interests, the current study reflects the results of similar studies (e.g., Dunst, Trivette, \& Masiello, 2011). The value of interest-based interventions for youth with ASD has been recognized for a wide range of outcome goals (e.g., social skills, Jull \& Mirenda, 2010; academic skills, Koegel, Singh, \& Koegel, 2010) and as a central component of evidence-based therapeutic programs (e.g., pivotal response therapy, Koegel \& Koegel, 2012). Despite the wide adoption of interest-based practices, some misconceptions about interests of youth with ASD are still pervasive in the literature. For example, the interests of youth with ASD are generally considered to be narrow and have been described in the literature as circumscribed (Turner-Brown, Lam, Holtzclaw, Dichter, \& Bodfish, 2011), restricted (Mercier, Mottron, \& Belleville, 2000), and limited (Baron-Cohen \& Wheelwright, 1999; South, Ozonoff, \& McMahon, 2005). While some youth with ASD have narrow interests, the youths in the current study were able to identify a wide variety of activities that they found interesting. Much like the interests of typically developing youth, the interests of the youths in the current study were heterogeneous, individual, and wide-ranging. Rather than presuming that the interests of youth with ASD are restricted or fall into easy categories, program designers who want to incorporate interests into program design should work with the youth to identify which activities are genuinely of interest to them (Dunst et al., 2011). Identifying the individual interests of youth in the intervention prior to its design may be effortful, but the extra effort may be worth the time. Indeed, compared to programs that used situational interests, the effect sizes of programs that took the time to identify personal interests of the children with ASD were almost twice as large (Dunst, Trivette, \& Masiello, 2012).

Several parents and youths with ASD in the current study reported that helping others was a productive form of social interaction. The finding that youths with ASD develop when they are engaged in acts of contribution toward others may be relatively novel to the field of autism research, but it aligns with the findings of research on factors of thriving for typically developing youth (e.g., Lerner, Almerigi, Theokas, \& Lerner, 2005; Khanna, MacCormack, Kutsyuruba, McCart, \& Freeman, 2015). According to the framework of positive youth development (e.g., Five Cs model; Jelicic, Bobek, Phelps, Lerner, \& Lerner, 2007), positive contributions to self, family, community, and society are crucial to the well-being and development of typically developing youth. The results of the current study appear to show that youth with ASD may not be exceptions to that rule. Like parents of typically developing peers (Narumanchi \& Bhargava, 2011), parents of youth with ASD believe that their children can benefit by contributing service to others. Finding ways to engage youth with ASD by including opportunities to teach and support other youth may improve the effectiveness of programs designed for youth with ASD, especially for those youths who are high functioning.

\section{Factors Affecting Program Decisions}

The results of the current study extend the results of previous research (e.g., Lyons et al., 2010), demonstrating that parents are stressed by the task of supporting the needs of 
youth with ASD, especially during adolescence. Without exception, the parents in the current study reported that the challenge of finding programs for their children compounded the stress associated with parenting a child with ASD. Parents of youth with ASD are the engines of program decisions and implementation, and they have reported feeling stressed by the intense caretaking responsibilities (Jinnah \& Stoneman, 2008) and financial pressures (Jarbrink, Fombonne, \& Knapp, 2003) that come with being a parent of a youth with ASD. According to Siklos and Kerns (2006), most parents have difficulty accessing services for their child, such as developmentally appropriate after-school activities (77\%), opportunities to play with typically developing youth (64\%), and financial support to provide for therapies and services (93\%). The stress experienced by parents of youth with ASD does not lessen as the youth get older. As children move into adolescence, their social networks become more complex and their relationships become more mature (Tobias, 2009). Much like the participants in other studies, parents in the current study reported that the increased social demands of adolescence impacted their children and compounded the stress experienced by the parents. Considering how program decisions are affected by stress (Brookman-Frazee, 2004; Hodgetts et al., 2013), reducing parental stress should be a primary concern for practitioners who support the development of older youth with ASD (Burrell \& Borrego, 2012).

As noted in previous studies (e.g., MacCormack et al., 2015), providers of community-based programs play an important role as service designers, especially for families who do not have regular access to clinical programs. Unfortunately, communitybased programs do not always incorporate the best empirical evidence (Drahota, Aarons, \& Stahmer, 2012; Ratcliffe, Wong, Dossetor, \& Hayes, 2014; Stadnick, Stahmer, \& Brookeman-Frazee, 2015), so families who are desperate to find effective, accessible social programs instead find poorly designed programs that do little more than serve as network hubs. Future studies should focus on how evidence-based practices can be meaningfully incorporated into community-based programs.

\section{Limitations}

There are two main limitations to this study. The first limitation relates to the sample, which was restricted by recruitment scope and by size. While focusing on 12 families allowed for more comprehensive interviews than might be plausibly expected from a larger sample study, the small sample size (i.e., 12 youths, 15 parents) may reduce the generalizability of the results of the study. Participants for this study were recruited through social media, listservs of autism associations, and personal networks in several regions in southern Ontario. For this reason, the results may not represent the perspectives of parents unaffiliated with autism associations and those who live outside of the catchment area.

The second limitation of the study is the representation of the participants. While youths were included in the interviews, the perspectives of the parents were used more often than those of the youths. Youth perspectives were limited by their social and communication difficulties, which are characteristic of their diagnoses. The inclusion of the perspectives of the youth in the current study, albeit in a limited capacity, offers an important contribution because the voices of youth participants are crucial components of 
programming decisions. The current study relied on the perspectives of mostly female parents and mostly male youths participants. Even though parental perspectives from a disproportionate gender divide (i.e., mostly female parents) is a limitation common in autism research and the broader field of disability studies (Woodgate, Ateah, \& Secco, 2008), some studies suggest that there are significant differences between how mothers and fathers perceive programs and the development of their children. The perspectives of mothers can be very different from those of fathers on the importance of items related to after-school programs and services (e.g., "information about special programs and services available to my child and family," mothers $23.3 \%$, fathers $4.1 \%$; "have my child's therapies continue outside of school," mothers $27.4 \%$, fathers $6.8 \%$; Hartley \& Schultz, 2015). In terms of the youth participants, the gender divide in the current study was not proportionate to the gender differences of youths with ASD. Balancing the gender divide of youth participants is important because parents perceive autistic characteristics of boys differently than the characteristics of girls. Compared to the social difficulties of boys, the social difficulties of girls are rated as more problematic (Posserud, Lundervold, \& Gillberg, 2006). Also, parents of boys rated self-control as more important than did parents of girls (Rankin et al., 2015). Recruitment practices that include more proportionate representation of genders may provide a better view of the perspectives of youth with ASD and their parents.

\section{Concluding Comment}

Despite these limitations, the current study suggests that, when included in the development of programs, parents and the youth themselves can offer important contributions to the design of programs. For example, the parents and youths in the current study demonstrated that they believe that social competence programs need to do more than consider the youths' social needs; parents seek programs that also consider the youths' emotional well-being and reflect the youths' dynamic development. Despite the perception that parents do not understand the complexity of social competence and intervention, parents provided descriptions of their children's social competence that aligned with the findings of the SRS-2. Parents were also able to identify practices and services that they believed would help their children and to describe the factors that affected their program decisions. As the daunting task of navigating complex systems of programs and funding falls on parents, understanding the perceptions of parents and valuing their contributions may help program designers develop interventions in which families are willing to invest their time.

\section{References}

Alberta Education. (2006). Building on success: Helping students make transitions from year to year. Edmonton, AB: Author.

American Psychiatric Association [APA]. (2013). Diagnostic and statistical manual of mental disorders (5th ed.). Arlington, VA: Author.

Baron-Cohen, S., \& Wheelwright, S. (1999). 'Obsessions' in children with autism or Asperger syndrome: Content analysis in terms of core domains of cognition. British Journal of Psychiatry, 175, 484-490. 
Bauminger, N., Shulman, C., \& Agam, G. (2003). Peer interaction and loneliness in high-functioning children with autism. Journal of Autism and Development Disorders, 33, 489-507. doi:10.1023/A:1025827427901

Bauminger-Zviely, N. (2013). Social and academic abilities in children with high-functioning autism spectrum disorders. New York, NY: Guilford.

Begeer, S., Gevers, C., Clifford, P., Verhoeve, M., Kat, K., Hoddenbach, E., \& Boer, F. (2011). Theory of mind training in children with autism: A randomized controlled trial. Journal of Autism and Developmental Disorders, 41, 997-1006.

Bellini, S., Peters, J., Benner, L., \& Hopf, A. (2007). A meta-analysis of schoolbased social skills interventions for children with autism spectrum disorders. Remedial and Special Education, $28,153-162$.

Bitterman, A., Daley, T., Misra, S., Carlson, E., \& Markowitz, J. (2008). A national sample of preschoolers with autism spectrum disorders: Special education services and parent satisfaction. Journal of Autism and Developmental Disorders, 38, 1509-1517. doi:10.1007/s10803-007-0531-9

Brookman-Frazee, L. (2004). Using parent/clinician partnerships in parent education programs for children with autism. Journal of Positive Behavior Interventions, 4, 195-213.

Brookman-Frazee, L., Baker-Ericzen, M., Stadnick, N., \& Taylor, R. (2012). Parent perspectives on community mental health services for children with autism spectrum disorders. Journal of Child and Family Studies, 21, 533-544. doi:10.1007/s10826-011-9506-8

Burrell, T., \& Borrego, J., Jr. (2012). Parents' involvement in ASD treatment: What is their role? Cognitive and Behavioral Practice, 19, 423-432. doi:10.1016/j.cbpra.2011.04.003

Constantino, J. N., \& Gruber, C. P. (2012). Social Responsiveness Scale, Second Edition (SRS-2). Torrance, CA: Western Psychological Services.

Crane, L., Chester, J. W., Goddard, L., Henry, L. A., \& Hill, E. (2015). Experiences of autism diagnosis: A survey of over 1000 parents in the United Kingdom. Autism, 20, 153-162. doi: $10.1177 / 1362361315573636$

Cunningham, A. (2012). Measuring change in social interaction skills of young children with autism. Journal of Autism and Developmental Disabilities, 42, 593-605.

Dunst, C. J., Trivette, C. M., \& Hamby, D. W. (2007). Meta-analysis of family-centered helpgiving practices research. Mental Retardation and Developmental Disabilities Research Reviews, 13, 370-378.

Dunst, C., Trivette, C., \& Masiello, T. (2011). Exploratory investigation of the effects of interestbased learning on the development of young children with autism. Autism, 15, 295-305. doi:10.1177/1362361310370971.

Dunst, C., Trivette, C., \& Masiello, T. (2012). Meta-analysis of studies incorporating the interests of young children with autism spectrum disorders into early intervention practices. Autism Research and Treatment, 2012(462531), 1-10. doi:10.1155/2012/462531

Fontana, F., \& Frey, J. (2000). The interview: From structured questions to negotiated text. In N. K. Denzin \& Y. S. Lincoln (Eds.), Handbook of qualitative research (pp. 645-672). Thousand Oaks, CA: Sage.

Frey, J., Elliott, S., \& Kaiser, A. (2014). Social skills intervention planning for preschoolers: Using the SSiS-Rating Scales to identify target behaviors valued by parents and teachers. Assessment for Effective Intervention, 39, 182-192.

Gallagher, P., Floyd, J., Stafford, A., Taber, T., Brozovic, S., \& Alberto, P. (2000). Inclusion of students with moderate or severe disabilities in educational and community settings: 
Perspectives from parents and siblings. Education and Training in Mental Retardation and Developmental Disabilities, 35, 135-147.

Goin-Kochel, R., Mackintosh, V., \& Myers, B. (2009). Parental reports on the efficacy of treatments and therapies for their children with autism spectrum disorders. Research in Autism Spectrum Disorders, 3, 528-537. doi:10.1016/j.rasd.2008.11.001

Gresham, F., \& Lambros, K. (1998). Behavioral and functional assessment. In T. S. Watson \& F. M. Gresham (Eds.), Handbook of child behavior therapy (pp. 3-22). New York, NY: Plenum Press.

Hartley, S., \& Schultz, H. (2015). Support needs of fathers and mothers of children and adolescents with autism spectrum disorder. Journal of Autism and Developmental Disorders, 45, 16361648. doi:10.1007/s10803-014-2318-0

Hodgetts, S., Nicholas, D., Zwaigenbaum, L., \& McConnell, D. (2013). Parents' and professionals' perceptions of family-centered care for children with autism spectrum disorder across service sectors. Social Science \& Medicine, 96, 138-146. doi:10.1016/j.socscimed.2013.07.012

Hume, K., Bellini, S., \& Pratt, C. (2005). The usage and perceived outcomes of early intervention and early childhood programs for young children with autism spectrum disorder. Topics in Early Childhood Special Education, 25, 195-207.

Iadarola, S., Hetherington, S., Clinton, C., Dean, M., Reisinger, R., Huynh, L., ... Kasari, C. (2015). Services for children with autism spectrum disorder in three, large urban school districts: Perspectives of parents and educators. Autism, 19, 694-703. doi:10.1177/1362361314548078

Jarbrink, K., Fombonne, E., \& Knapp, M. (2003). Measuring the parental, service and cost impacts of children with autism spectrum disorder: A pilot study. Journal of Autism and Developmental Disorder, 33, 395-402.

Jelicic, H., Bobek, D., Phelps, E., Lerner, R., \& Lerner, J. (2007). Using positive youth development to predict contribution and risk behaviors in early adolescence: Findings from the first two waves of the 4-H study of positive youth development. International Journal of Behavioral Development, 31, 263-273. doi:10.1177/0165025407076439

Jinnah, H. A., \& Stoneman, Z. (2008). Parents' experiences in seeking childcare for school age children with disabilities: Where is the breakdown? Children and Youth Services Review, 30, 967-977.

Keenan, M., Dillenburger, K., Doherty, A., Byrne, T., \& Gallagher, S. (2010). The experiences of parents during diagnosis and forward planning for children with autism spectrum disorder. Journal of Applied Research in Intellectual Disabilities, 23, 390-397.

Khanna, N., MacCormack, J., Kutsyuruba, B., McCart, S., \& Freeman, J. (2015). "Discovering" critical factors for youth thriving: Using Grounded Theory rigorous review method. Graduate Symposium Selected Papers, 9, 35-50.

Kissel, S. D., \& Nelson, W. M. (2014). Parents' perceptions of the severity of their child's autistic behaviors and differences in parental stress, family functioning, and social support. Focus on Autism and Other Developmental Disabilities, 31(2), 152-160. doi:10.1177/1088357614537352

Klin, A., Danovitch, J., Merz, A., \& Volkmar, F. (2007). Circumscribed interests in higher functioning individuals with autism spectrum disorders: An exploratory study. Research \& Practice for Persons with Severe Disabilities, 32, 89-100.

Koegel, R., \& Koegel, L. (2012). The PRT pocket guide. Baltimore, MD: Paul H. Brookes.

Koegel, L., Singh, A., \& Koegel, R. (2010). Improving motivation for academics in children with autism. Journal of Autism and Developmental Disorders, 40, 1057-1066. doi:10.1007/s10803-010-0962-6. 
Kohler, F. (1999). Examining the services received by young children with autism and their families: A survey of parent responses. Focus on Autism and Other Developmental Disorders, 14, $150-159$.

Laugeson, E. A., Frankel, F., Gantman, A., Dillon, A. R., \& Mogil, C. (2012). Evidence-based social skills training for adolescents with autism spectrum disorders: The UCLA PEERS program. Journal of Autism and Developmental Disorders, 42, 1025-1036.

Laugeson, E., Ellingsen, R., Sanderson, J., Tucci, L., \& Bates, S. (2014). The ABC's of teaching social skills to adolescents with autism spectrum disorder in the classroom: The UCLA PEERS program. Journal of Autism and Developmental Disorders, 44, 2244-2256. doi:10.1007/s10803-014-2108-8

Laursen, B., \& Hartl, A. (2013). Understanding loneliness during adolescence: Developmental changes that increase the risk of perceived social isolation. Journal of Adolescence, 36, $1261-1268$.

LeGoff, D. B. (2004). Use of $\mathrm{LEGO}^{\odot}$ as a therapeutic medium for improving social competence. Journal of Autism and Developmental Disorders, 34, 557-571. doi:10.1007/s10803-004$2550-0$

Lerner, R., Almerigi, J., Theokas, C., \& Lerner, J. (2005). Positive youth development: A view of the issues. Journal of Early Adolescence, 25, 10-16. doi:10.1177/0272431604273211

Locke, J., Ishijima, E., Kasari, C., \& London, C. (2010). Loneliness, friendship quality and the social networks of adolescents with high-functioning autism in an inclusive school setting. Journal of Research in Special Education Needs, 10, 78-81. doi:10.1111/j.1471-3802.2010.01148.x

Locke, J., Shih, W., Kretzmann, M., \& Kasari, C. (2015). Examining playground engagement between elementary school children with and without autism spectrum disorder. Autism, 1, 1-10. doi: $10.1177 / 1362361315599468$

Lyons, A., Leon, S., Roecher Phelps, C., \& Dunleavy, A. (2010). The impact of child symptom severity on stress among parents of children with ASD: The moderating role of coping styles. Journal of Child and Family Studies, 19, 516-524.

MacCormack, J., Matheson, I., \& Hutchinson, N. (2015). An exploration of a community-based LEGO $^{\circledR}$ social-skills program for youth with autism spectrum disorder. Exceptionality Education International, 25, 13-32.

Mack, N., Woodsong, C., MacQueen, K., Guest, G., \& Namey, E. (2005). Qualitative research methods: A data collector's field guide. Durham, NC: Family Health International.

Martens, B., Witt, J., Elliot, S., \& Darveaux D. (1985). Teacher judgments concerning the acceptability of school-based interventions. Professional Psychology: Research \& Practice, 16, 191-198.

Matson, J., Matson, M., \& Rivet, T. (2007). Social-skills treatments for children with autism spectrum disorders: An overview. Behavior Modification, 31, 682-707.

McMahon, C. M., Lerner, M. D., \& Britton, N. (2013). Group-based social skills interventions for adolescents with higher-functioning autism spectrum disorder: A review and looking to the future. Adolescent Health, Medicine and Therapeutics, 4, 23-28.

Mercier, C., Mottron, L., \& Belleville, S. (2000). A psychosocial study on restricted interests in highfunctioning persons with pervasive developmental disorders. Autism, 4, 406-425. doi: $10.1177 / 1362361300004004006$

Narumanchi, A., \& Bhargava, S. (2011). Perceptions of parents of typical children towards inclusive education. Disability, CBR, and Inclusive Development, 22, 120-129. doi:10.5463/DCID.v22i1.10 
Norbury, C. F. (2005). The relationship between theory of mind and metaphor: Evidence from children with language impairment and autistic spectrum disorder. British Journal of Developmental Psychology, 23, 383-399.

Noyes-Grosser, D., Rosas, S., Goldman, A., Elbaum, B., Romanczyk, R., \& Callahan, E. (2013). Conceptualizing child and family outcomes of early intervention services for children with ASD and their families. Journal of Early Intervention, 35, 332-354. doi: $10.1177 / 1053815114551415$

Ozonoff, S., Goodlin-Jones, B., \& Solomon, M. (2005). Evidence-based assessment of autism spectrum disorders in children and adolescents. Journal of Clinical Child \& Adolescent Psychology, 34, 523-540.

Posserud, M., Lundervold, A., \& Gillberg, C. (2006). Autistic features in a total population of 7-9year-old children assessed by the ASSQ (Autism Spectrum Screening Questionnaire). Journal of Child Psychology and Psychiatry, 47, 167-175.

Rankin, J. A., Weber, R. J., Kang, E., \& Lerner, M. D. (2015). Parent- and self-reported social skills importance in autism spectrum disorder. Journal of Autism and Developmental Disorders, 46, $273-286$.

Reichow, B., \& Volkmar, F. (2010). Social skills for interventions for individuals with autism: Evaluation for evidence-based practices within a best evidence synthesis framework. Journal of Autism and Developmental Disorders, 40, 149-166.

Rogers, S. J., Vismara, L., Wagner, A. L., McCormick, C., Young, G., \& Ozonoff, S. (2014). Autism treatment in the first year of life: A pilot study of infant start, a parent-implemented intervention for symptomatic infants. Journal of Autism and Developmental Disorders, 44(12), 2981-2995.

Russell, S., \& McCloskey, C. (2015). Parent perceptions of care received by children with an autism spectrum disorder. Journal of Pediatric Nursing: Nursing Care of Children and Families, 31, $21-31$.

Siklos, S., \& Kerns, K. (2006). Assessing need for social support in parents of children with autism and Down syndrome. Journal of Autism and Developmental Disorders, 36, 921-933.

South, M., Ozonoff, S., \& McMahon, W. (2005). Repetitive behavior profiles in Asperger syndrome and high-functioning autism. Journal of Autism and Developmental Disorders, 35, 145-158. doi:10.1007/s10803-004-1992-8

Stahmer, A. C., Brookman-Frazee, L., Rieth, S. R., Stoner, J. T., Feder, J. D., Searcy, K., \& Wang, T. (2017). Parent perceptions of an adapted evidence-based practice for toddlers with autism in a community setting. Autism, 21, 217-230. doi:10.1177/1362361316637580

Stoner, J., Angell, M., House, J., \& Bock, S. (2007). Transitions: Perspectives from parents of young children with autism spectrum disorder (ASD). Journal of Developmental and Physical Disabilities, 19, 23-39. doi:10.1007/s10882-007-9034-z

Stoner, J., Bock, S., Thompson, J., Angell, M., Heyl, B., \& Crowley, E. (2005). Welcome to our world: Parent perceptions of interactions between parents of young children with ASD and education professionals. Focus on Autism and Other Developmental Disabilities, 20, 39-51.

Tantam, D. (2000). Adolescence and adulthood of individuals with Asperger syndrome. In A. Klin, F. R. Volkmar, \& S. Sparrow (Eds.), Asperger syndrome (pp. 87-102). New York, NY: Guilford Press.

Taylor, J., \& Seltzer, M. (2011). Employment and post-secondary educational activities for young adults with autism spectrum disorders during the transition to adulthood. Journal of Autism Developmental Disorders, 41, 566-574. 
Tobias, A. (2009). Supporting students with autistic spectrum disorder (ASD) at secondary school: A parent and student perspective. Educational Psychology in Practice, 25, 151-165.

Tracy, J., Robins, R., Schriber, R., \& Solomon, M. (2011). Is emotional recognition impaired in individuals with autism spectrum disorders? Journal of Autism and Developmental Disorders, 41, 102-109.

Tucker, V., \& Schwartz, I. (2013). Parents' perspectives of collaboration with school professionals: Barriers and facilitators to successful partnerships in planning for students with ASD. School Mental Health, 5, 3-14. doi:10.1007/s12310-012-9102-0

Turner-Brown, L., Lam, K., Holtzclaw, T., Dichter, G., \& Bodfish, J. (2011). Phenomenology and measurement of circumscribed interests in autism spectrum disorders. Autism, 15, 437-456. doi: $10.1177 / 1362361310386507$

Wetherby, A. M., Guthrie, W., Woods, J., Schatschneider, C., Holland, R. D., Morgan, L., \& Lord, C. (2014). Parent-implemented social intervention for toddlers with autism: An RCT. Pediatrics, 134(6), 1084-1093.

White, S., Keonig, K., \& Scahill, L. (2007). Social skills development in children with autism spectrum disorders: A review of the intervention research. Journal of Autism and Developmental Disorders, 37, 1858-1868. doi:10.1007/s10803-006-0320-x

Woodgate, R., Ateah, C., \& Secco, L. (2008). Living in a world of our own: The experience of parents who have a child with autism. Qualitative Health Research, 18, 1075-1083. doi: $10.1177 / 1049732308320112$

\section{Author's Note}

The author is enthusiastically open to questions, comments, or discussion on the topics of parental perspectives, program design, and (dis)ability. Correspondence concerning this article should be addressed to him, Jeffrey W. H. MacCormack, 4401 University Drive, TH 258, Faculty of Education, Lethbridge, Alberta, T1K3M4, Canada. Email: jeffrey.maccormack@uleth.ca 


\section{Appendix A: Interview Questions}

With youth and parent (directed at youth, adapted from Baron-Cohen \& Wheelwright, 1999; comprehension level, Grade 3)

1. I would like to talk to you about your interests and favourite things to do. Is that okay?

2. What are some of your favourite things to do?

3. What do you love to do more than anyone else you know?

4. I would like to talk to you about your friends and how you all get along. I want you to think of someone around your age who you feel close with. Can you tell me a little about how it is between you?

5. I would like to talk about how well you get along with others at school or other places. How well do you get along with others?

6. How well do you co-operate with others while playing?

Previous programs (directed at parent and possibly youth, adapted from the Learner Profile questionnaire; Alberta Education, 2006)

1. I would like to talk to you about the programs and services that (youth's name) has already participated in. Is that okay?

2. In which programs has (youth's name) already participated (e.g., after-school clubs, community-based programs, clinical interventions)?

2b. How do you decide which programs and services are appropriate for (youth's name)?

3. In what ways have those programs helped (youth's name)?

4. In what ways have those programs not helped (youth's name)?

5. What do you (youth) think of these programs?

6. What do you (parent) think of these programs?

6 b. If you could design a perfect program for (youth's name) what would it include?

Interests and leisure activities (directed at parent and possibly youth, adapted from Yale Special Interests Survey; Klin et al., 2007)

1. I would like to talk to you about (youth's name) interests and leisure activities. Is that okay?

2. What topics are most interesting to (youth's name)?

3. What does (youth's name) prefer to do during leisure time?

4. When left alone, how much time does (youth's name) spend on topics of special interest?

5. If (youth's name) has an obsession with a topic, could you explain what form the obsession takes (e.g., machines, systems, sorting/categorizing, belief systems, sports/games)?

Social challenges and goals for social development (directed at parent and possibly youth, adapted from the Intervention Rating Scale; Martens et al., 1985)

1. I would like to talk to you about your child's social challenges and your goals for his or her social development. Is that okay?

2. What are (youth's name) experiences socializing to this point?

3. What skills do you think would help (youth's name) socialize more capably?

4. To what extent do you think learning to collaborate while playing with others is valuable to (youth's name) development?

5. To what extent do you think learning to initiate social interactions while playing with others is valuable to (youth's name) development?

6. What goals have you set for (youth's name) social development? 


\section{Appendix B: Overview of Perspectives of Participants and Program Experiences}

\begin{tabular}{|c|c|c|c|c|c|}
\hline \multirow[t]{2}{*}{ Parents } & Youth & Barriers & Weaknesses & Strengths & Goals \\
\hline & & - Program Experiences & Type & Duration & Format \\
\hline \multirow[t]{4}{*}{ Jeannie, Adrian } & David & time and cost, location & $\begin{array}{l}\text { not set to his needs } \\
\text { (processing speed) }\end{array}$ & group interactions & speaking kindly, empathy \\
\hline & & - YMCA social clubs & community-based & 1 hour per week for 10 weeks & casual \\
\hline & & - Church youth social group & community-based & 1 hour per week continuous & casual \\
\hline & - Soci & ial programs through school & school-based & 30-minute session per school day & casual \\
\hline \multirow[t]{5}{*}{ Lynette, Erik } & Janey & cost & $\begin{array}{l}\text { not for specific needs } \\
\text { (Janey is too advanced) }\end{array}$ & communication, parent instruction & interacting with groups \\
\hline & & - Speech language program & clinical & 1 hour per week for 12 weeks, & formal \\
\hline & & - Occupational therapy & clinical & 1 hour per week for a year & formal \\
\hline & & Summer school, social club & community-based & $\begin{array}{l}2-3 \text { hours per day through } \\
\text { summer }\end{array}$ & casual \\
\hline & - Preschool spe & eech and language program & school-based & $\begin{array}{l}\text { an hour per week throughout } \\
\text { school year }\end{array}$ & formal \\
\hline \multirow[t]{4}{*}{ Darla, Tony } & Charlie & cost, time commitment & $\begin{array}{l}\text { not set for his goals } \\
\text { (initiations) }\end{array}$ & helped with receptive language & $\begin{array}{l}\text { clear speech, ability to ask } \\
\text { questions }\end{array}$ \\
\hline & - Intensive bel & haviour intervention therapy & clinical & 30 hours per month continuous & formal \\
\hline & & - Private therapy & clinical & 10 hours per month continuous & formal \\
\hline & - Local au & tism group swimming social & community-based & $\begin{array}{l}30 \text { minutes per week for } 10 \\
\text { weeks }\end{array}$ & casual \\
\hline \multirow[t]{6}{*}{ Lori } & Gene & location & $\begin{array}{l}\text { not for his specific needs } \\
\text { (groups) }\end{array}$ & teaching others & $\begin{array}{l}\text { learn to play (lose } \\
\text { gracefully), less aggression }\end{array}$ \\
\hline & & - Behaviour social services & clinical & 1 hour per week for two years & formal \\
\hline & - Applied & behaviour analysis therapy & clinical & 1 hour per week continuous & formal \\
\hline & & - Comic book social club & community-based & 1 hour per week & casual \\
\hline & & - Community living & community-based & 1 hour per week, & casual \\
\hline & - Auti & sm Ontario social programs & community-based & 1 hour per week, & casual \\
\hline \multirow[t]{2}{*}{ Irene } & Frederick & $\begin{array}{l}\text { less access for high- } \\
\text { functioning kids }\end{array}$ & $\begin{array}{l}\text { not suited for development } \\
\text { (high functioning) }\end{array}$ & $\begin{array}{l}\text { learning to interact with the other } \\
\text { kids was better than the actual } \\
\text { program }\end{array}$ & $\begin{array}{l}\text { getting out of his comfort } \\
\text { zone, financial literacy }\end{array}$ \\
\hline & & - Local autism groups & community-based & 1 hour per week & casual \\
\hline
\end{tabular}




\section{Appendix B, cont'd}

\begin{tabular}{|c|c|c|c|c|c|}
\hline \multirow[t]{2}{*}{ Parents } & Youth & Barriers & Weaknesses & Strengths & Goals \\
\hline & & - Program Experiences & Type & Duration & Format \\
\hline \multirow[t]{4}{*}{ Grace } & Ben & $\begin{array}{l}\text { cost, program } \\
\text { requirements }\end{array}$ & not at his level & evidence-based with clear goals & $\begin{array}{l}\text { learn to collaborate, anger } \\
\text { management }\end{array}$ \\
\hline & & - Let's Socialize program & community-based & 1 hour per week & casual \\
\hline & - Social skills & with special education coach & school-based & $\begin{array}{l}30 \text { hours per month during school } \\
\text { year }\end{array}$ & formal \\
\hline & & - Local autism social groups & community-based & 1 hour per week for 10 weeks & casual \\
\hline \multirow{4}{*}{ Carolyn } & & - Private speech therapy & clinical & $\begin{array}{l}2 \text { hours per week for } 10 \text { weeks } \\
\text { continuous }\end{array}$ & - \\
\hline & - Hospital & social competence program & clinical & duration unspecified & - \\
\hline & & - Private therapist & clinical & 2 hours per week continuous & formal \\
\hline & & - Outdoor camp therapy & community-based & weeklong overnight camp & - \\
\hline \multirow[t]{4}{*}{ Erin } & Maurice & cost & not at his needs & $\begin{array}{l}\text { opportunities to see how social } \\
\text { world works }\end{array}$ & $\begin{array}{l}\text { learn to joke, be motivated } \\
\text { to seek socializing }\end{array}$ \\
\hline & & - Local autism social clubs & community-based & 1 hours per week for 10 weeks & - \\
\hline & & - Clinical therapy & clinical & 2 hours per week continuous & - \\
\hline & & - Social theatre club & community-based & $\begin{array}{l}2 \text { hours per week during school } \\
\text { year }\end{array}$ & - \\
\hline \multirow[t]{6}{*}{ Kate } & Cesar & location & $\begin{array}{l}\text { rely on networks, not in his } \\
\text { interests }\end{array}$ & $\begin{array}{l}\text { structured after-school } \\
\text { programming }\end{array}$ & $\begin{array}{l}\text { more self-confidence, } \\
\text { socialize in larger groups }\end{array}$ \\
\hline & & - Boys and Girls social club & community-based & $\begin{array}{l}2 \text { hours per day drop-in, } \\
\text { throughout school year }\end{array}$ & - \\
\hline & & - Leaders-in-Training & school-based & $\begin{array}{l}\text { during recess every school day } \\
\text { during school year }\end{array}$ & - \\
\hline & - Social c & lubs through the local library & community-based & 1 hour per week for 8 weeks & - \\
\hline & & - Local autism programs & community-based & 1 hour per week for 8 weeks & - \\
\hline & & - Applied behaviour analysis & clinical & 10 week sessions & formal \\
\hline
\end{tabular}

145 Exceptionality Education International, 2017, Vol. 27, No. 1 


\section{Appendix B, cont'd}

\begin{tabular}{|c|c|c|c|c|c|}
\hline \multirow[t]{2}{*}{ Parents } & Youth & Barriers & Weaknesses & Strengths & Goals \\
\hline & & - Program Experiences & Type & Duration & Format \\
\hline \multirow[t]{3}{*}{ Cheryl } & Terrell & location & $\begin{array}{l}\text { not at his level, short } \\
\text { programming }\end{array}$ & $\begin{array}{l}\text { evidence based (PEERS), } \\
\text { helping others }\end{array}$ & $\begin{array}{l}\text { learn to be patient while } \\
\text { speaking (guide job) }\end{array}$ \\
\hline & & - Private therapy & clinical & 4 hours per week continuous & - \\
\hline & & Outdoor centre social camp & community-based & $\begin{array}{l}\text { overnight camp, } 1 \text { week per } \\
\text { summer }\end{array}$ & - \\
\hline \multirow{3}{*}{ Gretchen } & & peech language pathologist & clinical & 1-2 hours per week continuous & - \\
\hline & $\begin{array}{r}\text { - In-pa } \\
\text { em }\end{array}$ & $\begin{array}{l}\text { tient psychiatric program for } \\
\text { otional regulation socializing }\end{array}$ & clinical & $\begin{array}{l}\text { overnight for five days a week for } \\
12 \text { weeks }\end{array}$ & formal \\
\hline & & - Gymnastics social group & community-based & 1 hour per week for 10 weeks & casual \\
\hline \multirow{4}{*}{ Maxine } & - University & based Mindfulness program & clinical & 2 hours per week & formal \\
\hline & - Loca & I autism Teen Cuisine group & community-based & 1 hour per week for 8 weeks & casual \\
\hline & & Autism Ontario social clubs & community-based & 1 hour per week continuous & casual \\
\hline & & - Social-skills outdoor camp & community-based & $\begin{array}{l}3 \text { hours on Saturday morning for } \\
8 \text { weeks }\end{array}$ & casual \\
\hline
\end{tabular}

